\title{
Pengolahan Terpadu Limbah Ternak di Kelompok Tani Rancamulya Sumedang
}

\author{
Integrated Processing of Livestock Waste in Rancamulya Sumedang Farmers \\ Eulis Tanti Marlina ${ }^{1, a}$, Yuli Astuti Hidayati ${ }^{1}$, D. Zamzam Badruzzaman ${ }^{1}$ \\ ${ }^{I}$ Fakultas Peternakan Universitas Padjadjaran \\ Jl. Raya Jatinangor Tlp. (022)7798241 Jatinangor-Majalengka 45363 \\ aemail:eulis.tanti@unpad.ac.id
}

\begin{abstract}
Abstrak
Penyuluhan pengolahan terpadu limbah ternak dilakukan di kelompok tani Rancamulya Desa Rancamulya Kecamatan Sumedang Utara Kabupaten Sumedang. Kegiatan penyuluhan merupakan bentuk diseminasi hasil penelitian untuk meningkatkan kualitas hidup masyarakat yang lebih baik. Pengolahan Limbah ternak secara terpadu yaitu pengolahan limbah ternak menghasilkan beberapa jenis produk seperti pupuk organik padat, pupuk organik cair, dan probiotik ternak dalam satu rangkaian pengolahan, meliputi fermentasi secara aerob dan anaerob fakultatif. Program ini dilakukan dengan metode penyuluhan dan demostrasi plot. Mitra merupakan masyarakat peternak yang tergabung dalam gabungan kelompok tani Desa Rancamulya. Pemeliharaan ternak pada umumnya masih dilakukan secara tradisional demikian juga pengolahan limbah ternak. Kesadaran masyarakat tentang arti penting pengelolaan limbah peternakan belum sepenuhnya dipraktekkan. Hal ini terjadi karena berbagai alasan seperti keterbatasan waktu yang dimiliki untuk mengolah limbah ternak. Oleh karena itu, dalam penyuluhan ini ditawarkan suatu pengolahan limbah secara terpadu dengan memaksimalkan hasil yang diperoleh dari pengolahan limbah dengan efisiensi waktu dan tempat pengolahan. Program penyuluhan ini selaras dengan rencana Pemerintahan Daerah Kabupaten Sumedang untuk meningkatkan sistem pertanian organik.
\end{abstract}

Kata Kunci: limbah ternak, pengolahan terpadu, sanitasi lingkungan, pupuk organik

\begin{abstract}
Extension of integrated processing of livestock waste was carried out in the Rancamulya farmer group in Rancamulya Village, North Sumedang, Sumedang District. Extension activities are a form of dissemination of research results to improve the quality of life for a better community. Integrated animal waste management, namely processing of livestock waste produces several types of products such as solid organic fertilizer, liquid organic fertilizer, and livestock probiotics in a series of processing, including aerobic and facultative anaerobes fermentation. The program is carried out by extension methods and demonstration. Partners is a community of farmers who are members of farmer group Rancamulya village. Production of livestock in general, is still traditionally as well as processing livestock waste. Public awareness of the importance of livestock waste management has not been fully put into pract. This happens due to various reasons such as limited time you have to treat livestock waste. Therefore, in this extension are offered an integrated waste processing to maximize the results obtained from waste processing efficiency and processing time. This extension program is in line with the plans of the Sumedang District Government to improve the organic farming system.
\end{abstract}

Keywords: animal waste, integrated processing, environmental sanitation, organic fertilizer 


\section{Pendahuluan}

Indonesia merupakan negara agraris, oleh karena itu usaha pertanian merupakan bagian yang tidak terpisahkan dengan masyarakat pedesaan. Sektor peternakan yang merupakan bagian dari pertanian berkembang menjadi penopang perekonomian masyarakat pedesaan. Saat ini Industri peternakan yang efisien menjadi tujuan untuk meningkatkan kualitas maupun kuantitas produksi, salah satunya adalah sistem peternakan terintegrasi. Sistem peternakan terintegrasi merupakan sistem peternakan yang mengintegrasikan kegiatan sektor peternakan beserta pendukungnya, meliputi kegiatan mengintegrasikan budidaya tanaman dan ternak (Siswati dan Nizar, 2012; Cahyono dkk., 2015). Limbah tanaman diolah menjadi pakan ternak, sedangkan limbah peternakan diolah menjadi pupuk organik, biogas, dan suplemen ternak.

Dewasa ini penggunaan pupuk organik untuk mendukung produktivitas tanaman pertanian semakin diminati seiring dengan meningkatnya kesadaran petani dalam membatasi penggunaan pupuk kimia. Disamping itu juga, kelangkaan pupuk bersubsidi menyebabkan harga pupuk kimia yang semakin tinggi. Tercatat harga pupuk urea yang beredar mencapai harga $\mathrm{Rp} 4.900$,/kg, pupuk ZA $2.900,-/ \mathrm{kg}$, pupuk NPK 6450,$/ \mathrm{kg}$ (Petro Gresik Indonesia, 2014).

Sejalan dengan bertambahnya permintaan pupuk organik sebagai pengganti pupuk anorganik, maka perkembangan harga pupuk kompos di pasaran cukup baik berkisar Rp1.500,- sampai Rp 3.000,- per kg. Sedangkan pupuk organik cair mempunyai harga yang sangat beragam dari $\mathrm{Rp} 25.000$,sampai Rp 130.000,- per liter. Hal ini menjadi peluang untuk masyarakat untuk dapat menghasilkan pupuk organik baik untuk memenuhi kebutuhan sendiri maupun untuk membuka usaha baru.

Limbah adalah bahan atau sisa material yang dihasilkan oleh suatu proses dan hampir tidak berharga atau tidak memiliki nilai guna sehingga nilai ekonominya sangat rendah (Merkel, 1981; Marlina dkk., 2013). Ternak dapat menghasilkan limbah 5-10\% bobot badan setiap harinya (Scmidt, dkk., 1998). Limbah yang pada awalnya memiliki nilai ekonomis rendah akan menjadi tinggi nilai ekonomisnya apabila dilakukan pengolahan secara tepat.
Limbah ternak berupa feses yang bercampur dengan urin tidak dapat langsung diaplikasikan ke tanaman sebagai pupuk. Hal ini disebabkan bahan organik dalam feses belum terurai menjadi unsur hara yang dapat diserap oleh tanaman. Dengan demikian pengolahan terlebih dahulu diperlukan agar limbah sapi dapat mempunyai nilai manfaat untuk tanaman. Beberapa alasan limbah ternak harus diolah terlebih dahulu sebelum digunakan, yaitu (1) penguraian bahan organik secara cepat akan mengganggu pertumbuhan tanaman, (2) pasokan unsur hara yang tersedia utuk tanaman sangat sedikit, (3) struktur bahan organik pada limbah segar sangat kasar daya serapnya rendah sehingga akan mengganggu proses penyerapan air oleh tanah, (4) ketersediaan limbah ternak tidak kontinyu sepanjang waktu sehingga menyimpan dalam bentuk kompos merupakan solusi yang baik sebelum digunakan sebagai pupuk (Prihandini dan Teguh, 2007). Upaya dalam menangani limbah ternak adalah dengan melakukan pengolahan menjadi pupuk organik, baik padat maupun cair. Salah satu cara yang dapat dilakukan adalah pengolahan limbah terpadu. Pengolahan terpadu merupakan suatu pengolahan limbah menjadi beberapa produk, yaitu pupuk organik cair (POC), pupuk organik padat (POP), dan probiotik dalam satu rangkaian pengolahan. Pupuk organik pada umumnya mengandung unsur hara yang lebih rendah dibandingkan dengan pupuk anorganik, namun demikian hasil penelitian menunjukkan pupuk organik mengandung mikroba fungsional yang dapat mendukung pertumbuhan tanaman, seperti bakteri yang berperan dalam nitrifikasi dan bakteri fiksasi $\mathrm{N}_{2}$ (Marlina dkk, 2017).

Potensi produksi pupuk organik di Kelompok Tani Rancamulya sangat baik. Desa Rancamulya terletak di Kecamatan Sumedang Utara Kabupaten Sumedang mempunyai luas wilayah 252,05 Ha dengan jumlah penduduk 7.333 jiwa (Monografi Desa Rancamulya, 2014). Peruntukan lahan untuk lahan pertanian mencapai $102,31 \mathrm{Ha}$ atau $40,6 \%$ total wilayah. Desa Rancamulya terletak di tempat strategis dengan akses jalan yang sangat baik, diantara 4 desa lain yakni Desa Cisalak di sebelah Utara, Desa Gunasari di sebelah selatan, Kelurahan Kotakaler di sebelah Barat, dan Desa Cikoneng di sebelah Timur. Dengan letak tofografi 500 dpl menjadikan Desa Rancamulya cocok untuk 
pengembangan ternak sapi perah. Beberapa jenis ternak yang dipelihara di Desa Rancamulya adalah ayam, itik, domba, sapi potong, sapi perah, kerbau, dan kuda (Direktorat Pemberdayaan Masyarakat Desa Departemen Dalam Negeri, 2014).

Dalam upaya peningkatan kesadaran terhadap kesehatan lingkungan melalui pendayagunaan limbah ternak di Desa Rancamulya Kabupaten Sumedang perlu dilakukan suatu upaya pembinaan yang berkesinambungan melalui penyuluhan dan pelatihan-pelatihan kepada masyarakat, khususnya anggota kelompok tani/ternak daerah tersebut. Pengolahan limbah ternak di daerah sasaran belum dilaksanakan maksimal, masih terbatas untuk memenuhi kebutuhan pupuk pertanian secara individu. Kegiatan penyuluhan ini diharapkan dapat meningkatkan pengetahuan dan keterampilan petani/peternak dalam menangani limbah ternak dengan mengolahnya menjadi pupuk organik untuk keperluan pertaniannya.

\section{Materi dan Metode Pelaksanaan}

Metode yang digunakan adalah penyuluhan dan demostrasi plot. Penetapan waktu pelaksanaan penyuluhan dikomunikasikan dan dikompromikan bersama masyarakat sehingga diperoleh waktu pelaksanaan yang tidak mengganggu aktivitas masyarakat. Hal ini merupakan upaya untuk mendapatkan respon yang positif dari masyarakat untuk hadir dalam kegiatan penyuluhan. Pengukuran keberhasilan penyuluhan dilakukan menggunakan uji pre test dan post test terhadap pengetahuan petani/peternak mengenai pengolahan limbah ternak.

Penyuluhan dilaksanakan di balai pertemuan dan pelaksanaannya meliputi pre test, penyampaian materi, dan diskusi. Pelatihan pembuatan pupuk organik dilakukan secara terpadu dengan diawali proses dekomposisi awal. Pembuatan pupuk organik, baik padat maupun cair dan probiotik dilakukan bersama-sama dengan membuat demplot oleh anggota kelompok tani/ternak. Kualitas pupuk organik hasil produksi peternak dianalisis di Laboratorium Kesuburan Tanah dan Nutrisi Tanaman, Departemen Ilmu Tanah dan Sumberdaya Lahan Fakultas Pertanian Universitas Padjadjaran.
Untuk melihat perubahan kognisi pada peserta penyuluhan dilakukan pre test dan post test. Data pre test dan post test dianalisis melalui perhitungan rata-rata (means), yaitu:

$$
\bar{X}=\frac{\Sigma X_{i}}{n}
$$

Dengan simpangan baku menggunakan rumus:

$\mathrm{S}=\sqrt{\frac{\Sigma\left(X_{i}-\bar{X}\right)^{2}}{n-1}}$

\section{Hasil dan Pembahasan}

Kegiatan penyuluhan pengolahan terpadu limbah ternak Kelompok Tani Rancamulya Sumedang telah terlaksana sampai pada tahap analisis produk pupuk yang dihasilkan. Kegiatan penyuluhan ini merupakan upaya dalam mengelola limbah ternak secara tepat sehingga tidak menimbulkan persoalan lingkungan sekitar dan meningkatkan nilai tambah limbah ternak. Pengolahan limbah terpadu diharapkan dapat meningkatkan pengetahuan masyarakat Desa Rancamulya dalam menyediakan pupuk organik untuk mendukung pertanian organik di wilayah Kabupaten Sumedang.

Kegiatan penyuluhan diawali dengan materi pengolahan limbah ternak secara terpadu, yaitu pengolahan limbah menjadi beberapa produk dalam satu rangkaian kegiatan. Produk yang dihasilkan berupa pupuk organik padat (vermicompost), pupuk organik cair, dan probiotik untuk ternak.

\section{Penyuluhan dan Demplot Pembuatan Limbah Ternak Terpadu}

Kegiatan diawali selanjutnya adalah melakukan demplot pengolahan limbah secara terpadu. Materi penyuluhan meliputi proses pengomposan yaitu mulai dari pemilihan bahan organik, factor-faktor yang mempengaruhi proses pengomposan, teknik pencampuran bahan baku mudah dan benar, serta mengetahui indicator kualitas kompos. Bahan organic yang banyak tersedia di Desa Rancamulya adalah limbah ternak domba dan sapi potong.

Dalam proses pengomposan, salah satu factor yang harus diperhatikan agar proses berjalan baik adalah kandungan nutrisi untuk mikroba pengurai yang dicerminkan dengan nisbah $\mathrm{C} / \mathrm{N}$. Nisbah $\mathrm{C} / \mathrm{N}$ yang ideal dalam proses pengomposan berkisar 25-40 (Merkel, 1981; Suryani, 2002; Azim et al., 2014). 
Tabel 1. Suhu Dekomposan Selama Dekompoisi Awal

\begin{tabular}{lccc}
\hline No. & Hari Ke- & \multicolumn{2}{c}{ Suhu $\left({ }^{\circ} \mathrm{C}\right)$} \\
\cline { 3 - 4 } & & Limbah Sapi Perah & Limbah Domba \\
\hline 1 & 1 & 30 & 30 \\
2 & 2 & 51 & 60 \\
3 & 3 & 53 & 66 \\
4 & 4 & 52 & 64 \\
5 & 5 & 44 & 59 \\
6 & 6 & 35 & 44 \\
7 & 7 & 30 & 32 \\
\hline
\end{tabular}

Feses domba dan feses sapi potong mempunyai nisbah $\mathrm{C} / \mathrm{N}$ yang rendah, yakni feses domba 15,27 dan feses sapi potong 21,5. Oleh karena itu perlu pencampuran feses ternak tersebut dengan bahan organic sumber karbon. Jerami padi merupakan salah satu bahan organic yang banyak tersedia di Desa Rancamulya.

Teknik pencampuran bahan organic dilakukan secara manual dengan diaduk, kemudian ditumpuk dalam karung urea, serta dilakukan proses dekomposisi selama 1 minggu secara aerob. Para peserta terlibat langsung secara aktif dalam proses pengomposan. Peserta mencatat suhu dekomposan selama proses dekomposisi. Suhu harian berkisar antara $30-66^{\circ} \mathrm{C}$ (Tabel 1).

Suhu merupakan salah satu indikator yang paling mudah untuk mengetahui proses pengomposan berjalan dengan baik. Suhu tinggi yang dicapai memberikan keuntungan yaitu tereduksinya bakteri pathogen dan gulma yang mempunyai dampak merugikan saat kompos diaplikasikan menjadi pupuk tanaman.

Setelah masa dekomposisi awal yang dilaksanakan selama 1 minggu selesai, dilakukan proses ekstraksi. Proses ektraksi dilakukan saat dekomposan sudah dianginangin selama 2 minggu sampai mencapai kadar air $\pm 20 \%$. Dari proses ekstraksi diperoleh bahan baku pembuatan POC, bahan baku pembuatan probiotik, dan bahan baku pembuatan vermicompost. Bahan baku untuk pembuatan POC diperoleh dengan mengekstrak dekomposan dengan air panas dengan perbandingan 1:4 (1 kg dekomposan kering menjadi 4 L POC). Proses inkubasi pupuk cair memakan waktu cukup lama, tergantung proses aerasi yang dilakukan. Proses aerasi harus dilakukan dengan cara mengaduk-aduk larutan setiap hari selama 15 menit atau menggunakan aerator. Panen dapat dilakukan apabila larutan sudah stabil dengan tanda-tanda diantaranya : tidak lagi berbau, tidak berbuih, berwarna hitam pekat yang bening (tembus cahaya) dan tidak terjadi endapan walaupun disimpan dalam jangka waktu lama. Setelah pemanenan dilakukan pengambilan sampel untuk dilakukan analisis kualitas pupuk di Laboratorium Kesuburan Tanah dan Nutrisi Tanaman Fakultas Pertanian Universitas Padjadjaran. Hal yang sama dilakukan pada vermicompost yang diperoleh (Tabel 2).

Bahan baku pembuatan probiotik diperoleh dari cairan ekstraksi yang sangat encer. Bahan tersebut difermentasi dengan menambahkan sumber energi siap pakai untuk bakteri berupa gula sederhana (gula pasir atau molases). Proses fermentasi probiotik dilakukan secara anaerob fakultatif menggunakan ember yang tertutup rapat. Probiotik akan bias dipanen setelah proses inkubasi selama 2 minggu. Probiotik dapat digunakan untuk Bahan baku pembuatan vermicompost diperoleh dari padatan residu ekstraksi. Proses vermicompost dilakukan dengan bantuan cacing tanah dalam dekomposisi bahan organik yang sebagian sudah diurai oleh mikroorganisme. Padatan residu ekstraksi digunakan sebagai media tumbuh cacing tanah sekaligus sumber nutrisi untuk pertumbuhan cacing tanah. Jenis cacing tanah yang dipelihara adalah Lumbricus rubellus. Hasil pemeliharaan cacing tanah selama 2 minggu diperoleh pupuk organic padat yang disebut vermicompost.

\section{Monitoring dan Evaluasi}

Monitoring dan evaluasi dilakukan secara bertahap pada setiap proses. Pada saat monitoring dijelaskan kegagalan dan hambatan yang terjadi disebabkan oleh berbagai faktor. Berbagai solusi dan pencegahan kegagalan didiskusikan dengan para peserta penyuluhan. Pada proses pembuatan probiotik, satu ember yang berisi larutan ekstrak yang telah ditambahkan molases mengalami kegagalan 
sedangkan 1 ember yang lain berhasil dengan baik. Kegagalan terjadi karena larutan ektrak terlalu penuh sehingga saat ditutup cairan luber dan membuat celah di sekitar tutup ember.

Proses fermentasi anaerob fakultatif tidak berjalan dengan baik. Pada Proses penanaman cacing tanah, tampak pertumbuhan cacing dan beberapa cacing sudah bertelur. Pada monitoring selanjutnya telur sudah menetas dan menjadi cacing muda yang siap dibesarkan di media tumbuh yang baru.

\section{Perubahan Kognisi Peserta Penyuluhan}

Salah satu pengukuran adanya peningkatan pengetahuan dan keterampilan peserta adalah melalui analisis perubahan antara nilai pre test dan post test. Sebelum penyuluhan, semua peserta yang hadir mengisi lembar kuisioner yang berisi pertanyaan terkait pengetahuan pengelolaan limbah ternak. Setelah selesai kegiatan penyuluhan selama 8 bulan, dilakukan post test dimana peserta mengisi kembali lembar kuisioner dengan pertanyaan yang sama dengan yang diberikan saat pre test. Hasil penilaian pre test dan post test disajikan pada Tabel 3.

Pengetahuan peserta mengenai pengolahan limbah terpadu pada umumnya masih rendah. Mayoritas peserta hanya mengetahui pengolahan limbah ternak secara konvensional, yakni limbah ternak dapat diolah menjadi kompos. Teknik pengolahan kompos yang baik serta persyaratan yang harus dipenuhi agar menghasilkan kualitas kompos yang baik belum dipahami oleh peserta. Hal ini tampak dari rataan pre test yang hanya mencapai nilai 45,25 . Nilai paling tinggi hanya dicapai oleh ketua gapoktan (75) karena sudah pernah mengikuti pelatihan pengolahan sampah organik di tingkat kabupaten.

Kemampuan kognitif adalah suatu kemampuan yang berhubungan dengan atau melibatkan kognisi (Damsar, 2011). Kognisi adalah proses memperoleh pengetahuan (Dimayati dan Mudjiono, 2006). Jika melihat peningkatan nilai test di akhir kegiatan penyuluhan sebesar $88,95 \%$, dapat dikatakan proses transfer pengetahuan pengolahan limbah ternak cukup baik. Hal ini sejalan dengan Mardikanto (2009) bahwa kegiatan penyuluhan dikatakan berhasil apabila materi yang disampaikan dengan penerapan metode dan teknik yang digunakan sesuai dengan kebutuhan serta kondisi pelaku utama sehingga dapat diterima dan dihayati serta diaplikasikan oleh masyarakat.

Tabel 2. Hasil Analisis Pupuk Organik

\begin{tabular}{|c|c|c|c|c|}
\hline No. & Parameter & Satuan & Pupuk Organik Cair & Pupuk Organik Padat \\
\hline & C-Organik & $\%$ & 2,06 & 1,89 \\
\hline & $\mathrm{pH}$ & - & 8,22 & 7,65 \\
\hline & Total N & $\%$ & 0,02 & 2,05 \\
\hline & $\mathrm{P}_{2} \mathrm{O} 5$ & $\%$ & 0,07 & 1,97 \\
\hline & $\mathrm{K}_{2} \mathrm{O}$ & $\%$ & 0,60 & 2,10 \\
\hline & Mikroba Fungsional & & & \\
\hline & Penambat N & $\mathrm{CFU} / \mathrm{ml}$ & $5,2 \times 10^{7}$ & $4,8 \times 10^{5}$ \\
\hline & Pelarut P & $\mathrm{CFU} / \mathrm{ml}$ & $8,00 \times 10^{8}$ & $7,5 \times 10^{7}$ \\
\hline & $\mathrm{Fe}$ & Ppm & 42,86 & 34,56 \\
\hline & $\mathrm{Mn}$ & Ppm & 5,43 & 4,35 \\
\hline & $\mathrm{Zn}$ & Ppm & 0,96 & 0,68 \\
\hline
\end{tabular}

Tabel 3. Tingkat pengetahuan peserta penyuluhan terhadap teknologi pengolahan limbah ternak

\begin{tabular}{ccc}
\hline No. & & Rataan Nilai \\
\hline 1 & Pre Test & $45,25 \pm 21,45$ \\
2 & Post Test & $88,50 \pm 10,95$ \\
\hline & Peningkatan Nilai & $88,95 \%$
\end{tabular}

Keterangan: Jumlah responden 23 orang; Kisaran nilai: 0-100 


\section{Kesimpulan}

Penyuluhan ini merupakan proses desiminasi hasil penelitian dari perguruan tinggi kepada para petani/peternak agar hasil penelitian dapat diaplikasikan langsung oleh masyarakat. Perencanaan pemerintah daerah Kabupaten Sumedang untuk meningkatkan pertanian organik dapat didukung melalui upaya peningkatan pengetahuan dan keterampilan masyarakat desa terhadap pembuatan pupuk organik asal limbah ternak.

\section{Ucapan Terima kasih}

Ucapan terima kasih diberikan kepada Direktorat Perguruan Tinggi atas pendanaan yang diberikan melalui program IbM tahun 2016, Direktorat Riset, PKM, dan Inovasi Universitas Padjadjaran yang telah memfasilitasi program IbM, serta Ketua dan anggota Gapoktan Rancamulya 1 dan 3 yang telah bekerjasama dengan baik sehingga terlaksananya kegiatan sesuai harapan.

\section{Daftar Pustaka}

Azim, K., Amellouk, A., Perossol, C., Thami Alami I., Soudi, B. 2014. Dynamic composting optimization through $\mathrm{C} / \mathrm{N}$ ratio variation as astart-up parameter. Proceedings of the $4^{\text {th }}$ ISOFAR Scientific Conference, Istambul Turkey.

Cahyono, A., A. Agus., B. Suhartanto. 2015. Pengembangan Sistem PertanianSiklusBio Terpadu untuk Peningkatan Produktivitas Ternak Sapi pada Kelompok Ternak Desa Margoagung, Sayegan, Sleman, Yogyakarta. Indonesian Journal of Community Engagement, Vol. 01(01) : 96-108.

Damsar. 2011. Pengantar Sosiologi Pendidikan. PT. Kencana Prenada Media Group. Jakarta.

Direktorat Pemberdayaan Masyarakat Desa Departemen Dalam Negeri, 2014. Monografi Desa Rancamulya Kecamatan Sumedang Utara Kabupaten Sumedang.
Dimayati dan Mudjiono. 2006. Belajar dan Pembelajaran. PT. Rineka Cipta, Jakarta Marlina, E.T. 2013. Analisis Kualitas Kompos dari Sludge Biogas Feses Kerbau. Jurnal Ilmu Ternak. Vol. 13(1) : 31-34.

Marlina, E.T., D. Z. Badruzzaman., I. Susilawati. 2017. Pengolahan Terpadu Limbah Sapi Potong menjadi PUPUK organik serta Aplikasinya Pada Pertumbuhan Rumput Gajah Odot (Pennisetum purpureum cv Mott). Laporan Penelitian. DRPMI Unpad, Bandung.

Merkel, J.A. 1981. Managing Livestock Waste. The AVI Publishing Company, Inc. Westport, Connecticut. Printed in The United States of America by Saybrook Press, Inc

http://pupukdolomite.indonetwork.co.id/37732 83/pupuk-npk-gresik-indonesia.htm Diunduh tanggal 18 April 2015.

http://isroi.com/2009/05/14/mikroba-yangdapat-menaikkan-ph-tanah/ Diunduh tanggal 21 April 2015.

Prihandini P, dan Teguh. 2007. Petunjuk Teknis Pembuatan Kompos Berbahan Kotoran Sapi . ISBN: 978-979-8308-758. Agro Inovasi Pusat Penelitian dan Pengembangan Peternakan.

Roostita B, E. Harlia, D. Suryanto. 2010. Jumlah Bakteri Total dan Koliform Susu Segar Peternakan Sapi Perah Rakyat dan Susu Pasteurisasi Tanpa Kemasan di Pedagang Kaki Lima. http://www.pustakakti.com/halaman.ph p

Siswati, L dan R. Nizar. 2012. Model Pertanian Terpadu Tanaman Holtikultura dan Ternak Sapi untuk Meningkatkan Pendapatan Petani. Jurnal Peternakan Indonesia, Juni 2012. ISSN 1907-1760. Vol. 14(2): 379-384.

Suryani, A. 2002. Bahan organic tanah. Institut Pertanian Bogor, Bogor.

Standar Nasional Indonesia. 2000. Batas Maksimum Cemaran Mikroba.

Schmidt, G.H., L.D. Van Vleck and M.F. Hutjens. 1988. Principles of Dairy Sceince. Prentice-Hall, Inc. New Jersey. USA. 